\title{
ANALISIS PROFIL VARIASI TEGANGAN DAN KEANDALAN LISTRIK JARINGAN TEGANGAN RENDAH PLN SEMARANG SELATAN BERBASIS DATA-LOGGER
}

\author{
Agus Adiwismono ${ }^{*}$, F. Danang Wijaya, Tiyono \\ Jurusan Teknik Elektro dan Teknologi Informasi, Fakultas Teknik, Universitas Gadjah Mada, Jalan Grafika No.2, \\ Yogyakarta, Indonesia 55281
}

\begin{abstract}
Abstrak
Pengukuran kualitas dan perhitungan keandalan listrik sampai saat ini masih diperoleh dari data secara manual. Diperlukan alat data-logger yang dapat merekam nilai tegangan (indikator kualitas), dan merekam lama-waktu-padam dan berapa-kali-padam (indikator keandalan) secara realtime, sehingga diperoleh data yang akurat, yang akan meningkatkan mutu dan pelayanan listrik dengan lebih efektif dan efisien. Berbasis data logger maka analisis profil variasi tegangan dapat langsung diketahui yaitu dalam bentuk gambar gelombang (profil) variasi tegangan, demikian pula analisis SAIDI dan SAIFI dapat langsung dilakukan, yaitu dari hasil rekam data selama pengukuran lalu dihitung dengan rumus. Hasil penelitian pada penyulang jaringan tegangan rendah (JTR) SRL01, variasi tegangan yang terjadi adalah: di pangkal penyulang Vmaks $=220 \mathrm{volt}, \mathrm{Vmin}=199 \mathrm{volt}$, dan di tengah penyulang Vmaks $=221$ volt, Vmin $=206 v o l t$, dan di ujung penyulang Vmaks $=221$ volt, Vmin $=200 \mathrm{volt}$; dibandingkan terhadap standar variasi Vmaks $=230 \mathrm{volt}$ dan Vmin $=197 \mathrm{volt}$, maka variasi tegangan yang terjadi sesuai standar. Dari perhitungan, angka lama padam (SAIDI) di sisi JTR penyulang SRL01 0,85 jam/pelanggan/bulan (belum memenuhi standar) dan angka kali padam (SAIFI) 1,05 kali/pelanggan/bulan (sudah memenuhi standar).
\end{abstract}

Kata kunci: data-logger; keandalan; kualitas

\begin{abstract}
[The Analysis of Voltage Variation Profile And Electrical Reliability of The Low Voltage Network Using Data-Logger In PLN of South Semarangl Manual measurement applied to the measurement of electricity quality and reliability has resulted in less accurate data. Data logger which records voltage value (quality indicator) and records the realtime duration and frequency of blackouts (reliability indicator) is needed to achieve accurate data, and improve the quality and services effectively and efficiently. By using the data logger the analysis of varied voltage profiles can directly be collected in the form of voltage wave (profiles), and therefore the analysis of SAIDI and SAIFI can be implemented. In the SRL01 low voltage (JTR) feeder, the form of the voltage shows: Vmax = 220 volt and Vmin $=199$ volt in starting point feeder, Vmax $=221$ volt and Vmin $=206$ volt in the middle feeder, Vmax $=221$ volt and Vmin $=220$ volt in the end point feeder. Compared to the consideration standard, which shows Vmax $=230$ voltand Vmin $=197$ volt, the result is appropriate. Based on the calculation interruption period quantity (SAIDI) in the side of JTR feeder SRL01 shows the number of 0,85 hour/customer/month (which means it's still under the standard) and interruption frequency quantity (SAIFI) shows the number of 1,05 time/ customer/month (which means it meets a demand with the standard).
\end{abstract}

Keywords: data-logger; reliability; quality

\section{Pendahuluan}

Pemerintah telah beberapa kali menaikkan dasar listrik (TDL). Konsekuensi yang terjadi apabila TDL naik, antara lain adalah masyarakat menuntut kepada operator listrik (dalam hal ini PLN), untuk meningkatkan kualitas listrik dan keandalan sistem pelayanan listrik. PLN mempunyai tolok ukur keberhasilan pengoperasian sistem distribusi/

\footnotetext{
*) Penulis Korespondensi.

E-mail: agusadi2012@gmail.com
}

pelayanan listrik, dengan melihat dari beberapa parameter antara lain: nilai tegangan listrik harus terjaga pada level tegangan pelayanan dan keandalan penyaluran tenaga listrik yang tinggi. Tegangan pelayanan ditentukan oleh batasan toleransi variasi tegangan, pada konsumen tegangan rendah maksimum $+5 \%$ dan minimum $-10 \%$ [1], artinya tegangan lebih (overvoltages) yang terjadi maksimum di atas $5 \%$ dari tegangan nominal, dan tegangan kurang (undervoltages) yang terjadi maksimum di bawah $10 \%$ dari tegangan nominal. Sedangkan indikator keandalan penyaluran tenaga listrik adalah 
angka lama padam dan atau seringnya padam pada pelanggan yang disebut dengan angka SAIDI (system average interruption duration index) dan SAIFI (system average interruption frequency index) [2]. Untuk Jawa-Bali target menantang yang diberikan direktur PLN pada tahun 2010 adalah mengalahkan Malaysia dalam hal kinerja operasi, yaitu listrik padam di Jawa-Bali harus lebih sedikit dari listrik padam di Malaysia.

Realisasi keandalan pasokan listrik kepada konsumen yang diukur dengan indikator SAIDI dan SAIFI jaringan PLN pada lima tahun terakhir dapat dilihat pada Tabel 1.

Tabel 1. Realisasi keandalan pasokan listrik Nasional [3]

Keandalan sistem distribusi dan pola operasi

\begin{tabular}{ccccccc}
\hline Tahun & $\mathbf{2 0 0 4}$ & $\mathbf{2 0 0 5}$ & $\mathbf{2 0 0 6}$ & $\mathbf{2 0 0 7}$ & $\mathbf{2 0 0 8}$ & $\mathbf{2 0 0 9}$ \\
\hline $\begin{array}{c}S A I D I \\
\text { (jam/Pe }\end{array}$ & 9,43 & 15,77 & 27,01 & 28,94 & 80,90 & 16,70 \\
$\begin{array}{c}\text { langgan } \\
\text { tahun) }\end{array}$ & & & & & & \\
\hline $\begin{array}{c}S A I F I \\
\text { (Kali/Pe }\end{array}$ & 11,78 & 12,68 & 13,85 & 12,77 & 13,33 & 10,78 \\
$\begin{array}{c}\text { langgan } \\
\text { /tahun) }\end{array}$ & & & & & & \\
\hline
\end{tabular}

mempunyai andil besar dalam pencapaian target SAIDI-SAIFI. Untuk menuangkan pelaporan yang valid, sering mengalami kendala klasik pada perhitungan SAIDI-SAIFI, antara lain :

1. Pelaksanaan pengisian laporan pemadaman belum seragam

2. Data jaringan tidak di up-date dengan baik, sehingga mana saja yang terkena pemadaman tidak terpantau dengan teliti

3. Data pelanggan/ gardu dan penjurusan jaringan tegangan rendah/ JTR belum tercatat dengan baik

4. Kemungkinan kesalahan baca pada alat ukur/ meter [4]

Ada beberapa aspek yang perlu diperhatikan dalam pendistribusian tenaga listrik yang menjadi standar minimal untuk pelayanan, atau sering disebut Tingkat Mutu Pelayanan (TMP). Mutu pelayanan penyediaan tenaga listrik di unit-unit PLN sesuai indikator pelayanan menyebutkan 13 jenis layanan dengan masing-masing indikatornya, diantaranya adalah :

a. Variasi tegangan rendah di titik pemakaian (Volt)

b. Lama gangguan tiap pelanggan (jam/pelanggan/ bulan)

c. Jumlah gangguan tiap pelanggan (kali/pelanggan/ bulan) [5].

Apabila nilai tegangan dan keandalan listrik rendah akan berpengaruh terhadap kinerja operasi distribusi, dan akan berdampak pada konsumen karena dapat merusak peralatan listrik dan mengganggu aktivitas yang menggunakan energi listrik.
Data nilai tegangan, berapa lama padam dan berapa kali padam suatu penyulang, diperoleh dari catatan secara manual (entri ke sistem pelaporan, termasuk pada sistem SCADA), sehingga dapat menimbulkan kurang akuratnya data yang bisa menyebabkan peningkatan kualitas dan keandalan listrik kurang efektif dan efisien.

Beberapa peneliti melakukan pengkajian tentang kualitas dan keandalan listrik, diantaranya sebagai berikut :

1. Tahun 2001, Suparyanto melakukan penelitian berjudul Perbaikan Kualitas Daya Sistem Distribusi Tenaga Listrik di PC GKBI Medari Sleman Yogyakarta. Data untuk mendukung penelitian ini yang berupa besaran-besaran listrik seperti arus, tegangan, daya, dan faktor daya, diperoleh dari pembacaan langsung pada alat-alat ukur analog di panel meter,

2. Desi Arisandi, pada tahun 2003 mengevaluasi keandalan sistem distribusi di PT PLN cabang Padang. Data yang dipergunakan untuk mengevaluasi keandalan tersebut yang berupa data jumlah pelanggan PLN, jumlah pelanggan yang mengalami pemadaman, dan lama padam pada pelanggan, didapat dari laporan rekapitulasi bulanan Unit Pelayanan Pelanggan (UPP).

3. Tahun 2008, Siti Saodah [6], mengkaji keandalan jaringan distribusi radial di PLN Cimahi UPJ Prima dengan menggunakan data sekunder, artinya data diperoleh hanya dari hasil rekap laporan pemadaman, sedangkan variasi tegangan tidak dilakukan pengkajian.

Pada penelitian yang penulis lakukan ini, data yang akan dianalisis diperoleh dari hasil rekam data secara real time menggunakan data logger, sehingga diharapkan hasil analisis akan lebih akurat. Analisis profil variasi tegangan dan keandalan listrik berbasis data logger, belum pernah dilakukan di PLN Semarang Selatan.

Dari latar belakang di atas, dan dengan memilih lokasi penelitian di wilayah PLN Semarang Selatan, serta waktu pengukuran bulan November 2011, dapat dirumuskan permasalahan-permasalahan sebagai berikut :

1. Berbasis data logger, apakah cukup mendukung analisis profil variasi tegangan (indikator kualitas listrik) pada distribusi JTR

2. Apakah variasi tegangan sesuai standar

3. Berbasis data logger, apakah cukup mendukung analisis SAIDI dan SAIFI (indikator keandalan listrik) pada distribusi JTR,

4. Apakah nilai SAIDI - SAIFI sesuai dengan standar.

Dan dari permalahan tersebut, maka tujuan penelitian ini adalah:

1. Membuktikan bahwa dengan berbasis data logger, cukup mendukung analisis profil variasi tegangan (indikator kualitas listrik) pada distribusi JTR 
2. Mengetahui apakah variasi tegangan sesuai dengan standar

3. Membuktikan bahwa dengan berbasis data logger, cukup mendukung analisis SAIDI dan SAIFI (indikator keandalan listrik) distribusi JTR

4. Mengetahui apakah nilai SAIDI dan SAIFI sesuai dengan standar

\subsection{Variasi tegangan}

Variasi tegangan disebabkan oleh jatuh tegangan (voltage drop) sebagai akibat kenaikan beban pada sebuah penyaluran juga disebabkan oleh diaktifkannya sistem line drop compensation pada pengatur tegangan sumber listriknya. Variasi tegangan yang melewati spesifikasi suatu peralatan akan mengurangi performansi alat tersebut. Standar variasi tegangan distribusi adalah sebesar $+5 \%,-10 \%$.

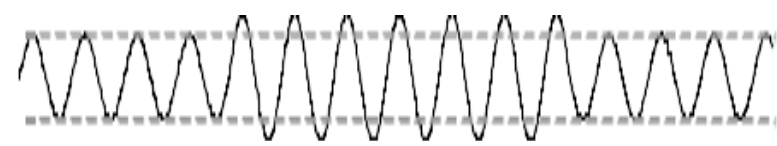

Gambar 1. Bentuk gelombang tegangan dengan variasi nilai tegangan [7]

\subsection{Keandalan listrik}

Keandalan adalah kemampuan sistem kelistrikan dalam menghadapi gangguan tanpa terjadi pemadaman [8]. Sebagai indikator keandalan penyaluran adalah angka lama padam dan atau seringnya pemadaman pada pelanggan yang disebut dengan angka SAIDI dan SAIFI.

Secara matematis angka SAIDI dihitung dengan rumus sebagai berikut :

$$
\mathrm{t} . \mathrm{n}
$$

$S A I D I=$------- (menit/pelanggan/tahun $)$
$\mathrm{N} . \mathrm{T}$

keterangan:

$\mathrm{t}=$ lama padam (menit)

$\mathrm{n}=$ jumlah pelanggan padam

$\mathrm{N}=$ jumlah total pelanggan

$\mathrm{T}=$ kurun waktu(tahun).

Angka sering padam : SAIFI (system average interruption frequency index) adalah indeks keandalan yang merupakan jumlah dari perkalian frekuensi padam dan pelanggan padam dibagi dengan jumlah pelanggan yang dilayani. Dengan indeks ini gambaran mengenai frekuensi kegagalan rata-rata yang terjadi pada bagian-bagian dari sistem bisa dievaluasi sehingga dapat dikelompokkan sesuai dengan tingkat keandalannya.

$$
\text { SAIFI } \left.=\frac{\mathrm{X} . \mathrm{n}}{\mathrm{N} . \mathrm{T}} \text {----- (kali/ pelanggan/tahun }\right)
$$

keterangan:

$\mathrm{X}=$ kali padam

$\mathrm{n}=$ jumlah pelanggan padam

$\mathrm{N}=$ jumlah total pelanggan

$\mathrm{T}=$ kurun waktu (tahun)

\subsection{Pengukuran variasi tegangan dan keandalan dengan Data Logger}

Data-logger dibuat khusus untuk mengukur parameter-parameter tegangan rendah, lama padam, dan berapa kali padam dalam kurun waktu tertentu. Berikut ini adalah bentuk ukuran alat data logger.

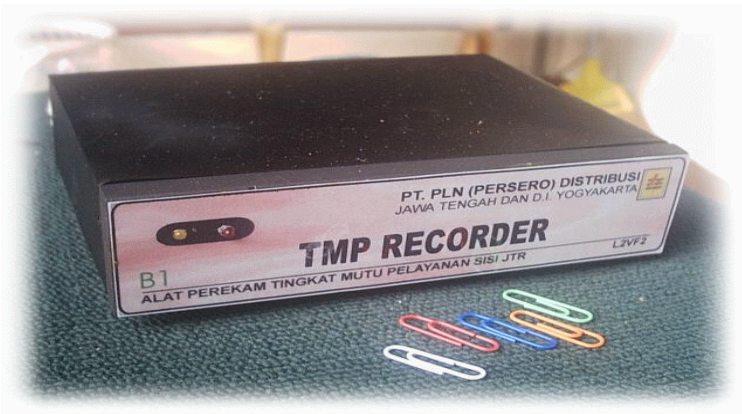

Gambar 2. Bentuk ukuran data logger [10]

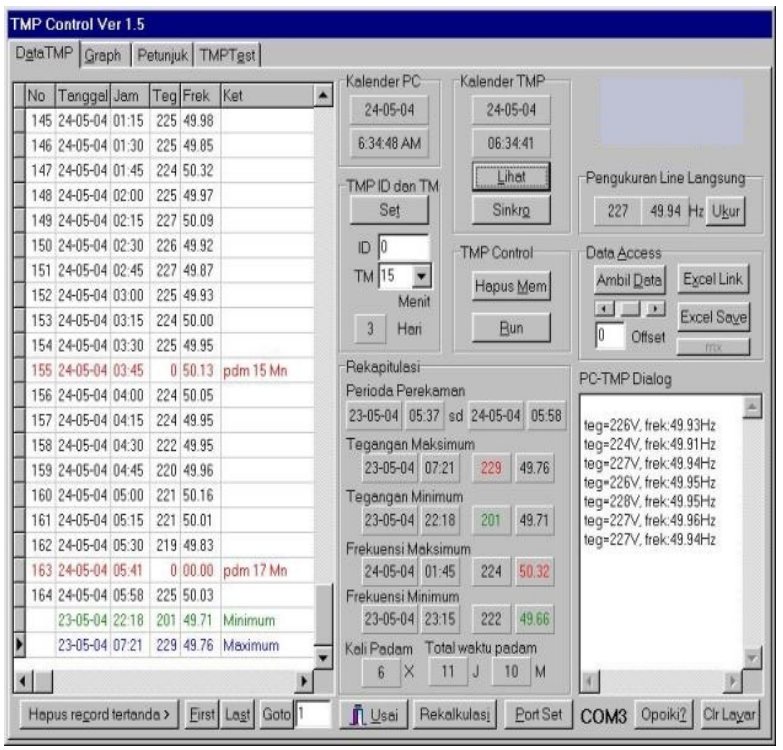

Gambar 3. Data Logger Interface PC/NoteBook [10]

\section{Bahan dan Metode}

Bahan atau objek yang diteliti adalah kelompok beban di PLN UPJ Semarang Selatan, yaitu JTR dari penyulang Srondol 01 (SRL01).

Alat penelitian berupa:

1. Data-logger sebanyak 3 buah (seperti terlihat pada gambar 1.2). Cara penyambungan alat data logger dengan JTR PLN adalah seperti berikut ini.

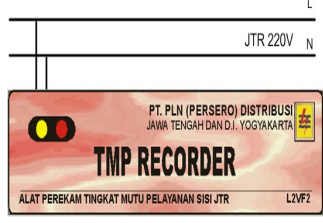

(a) tampak depan

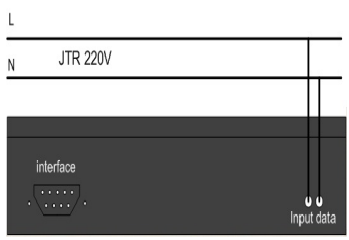

(b) tampak belakang
Gambar 5. Penyambungan data-logger pada JTR 


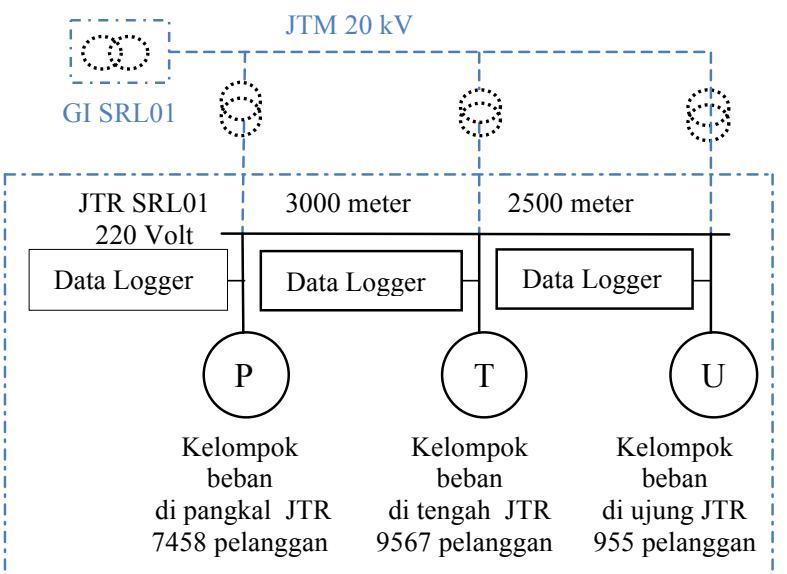

Gambar 4. Lokasi pemasangan data logger pada JTR penyulang SRL01

2. Program TMP.EXE Data logger diset dan diakses dengan PC dengan program TMP.EXE yang bekerja di Windows Operating System.

Tahapan penelitian dilaksanakan sesuai diagram alir sebagai berikut:

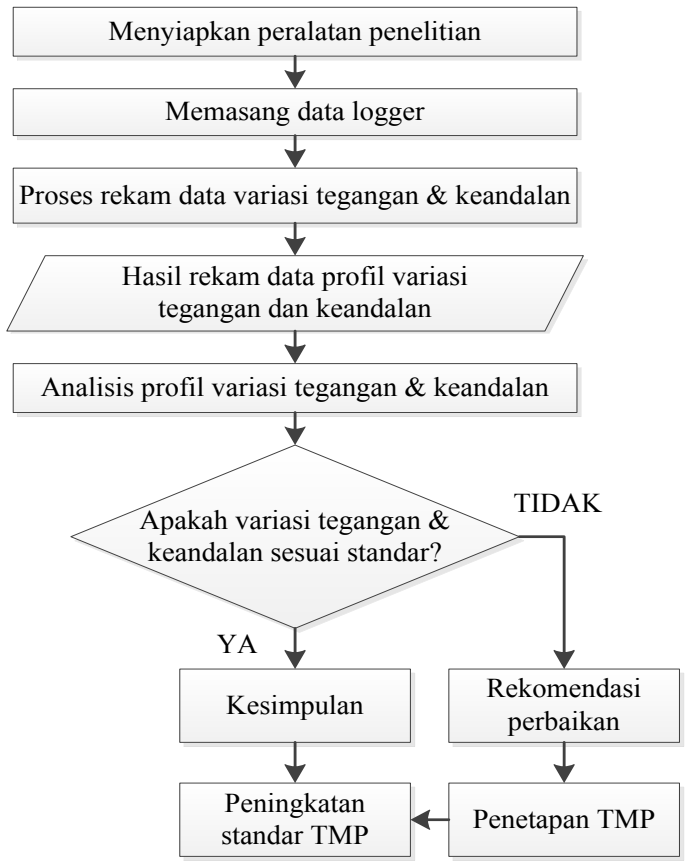

Gambar 6. Diagram alir prosedur penelitian

1. Menyiapkan alat dan bahan penelitian, dengan cara memilih 6 buah data logger yang sesuai dengan spesifikasi yang diperlukan.

2. Memasang alat data logger pada sisi JTR penyulang SRL01 3 (tiga) buah seperti terlihat pada Gambar 5 .

3. Setelah data logger terpasang, lalu dilakukan setting, maka proses rekam data berlangsung.

4. Analisis hasil rekam data variasi tegangan dan keandalan menggunakan pendekatan baik secara grafis maupun perhitungan.
5. Membandingkan hasil analisis terhadap nilai standar variasi tegangan dan keandalan listrik (SAIDI-SAIFI) yang tercantum pada deklarasi TMP.

6. Penyimpulan.

7. Memberikan rekomendasi perbaikan, apabila hasil analisis variasi tegangan dan keandalan tidak sesuai dengan standar.

Tabel 2. Deklarasi TMP PLN Semarang Selatan (2002) [5]

\begin{tabular}{lc}
\hline $\begin{array}{l}\text { Variasi tegangan } \\
\text { rendah: }\end{array}$ & $197-230$ Volt \\
\hline Lama gangguan: & 0,5 jam/pelanggan/bulan \\
\hline Jumlah gangguan: & $2.26 \mathrm{kali} /$ pelanggan/bulan \\
\hline
\end{tabular}

\section{Hasil dan Pembahasan}

3.1. Profil variasi tegangan JTR penyulang SRL01

Berdasarkan hasil rekam data selama pengukuran dapat dibuat grafik profil variasi tegangan seperti disajikan di Gambar 7.

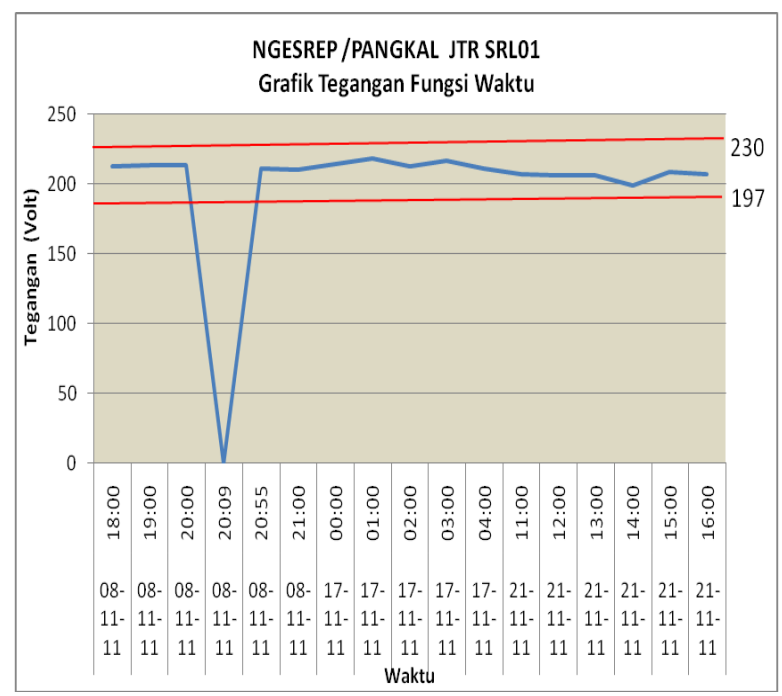

Gambar 7. Profil variasi tegangan di pangkal JTR penyulang SRL01

Dari Gambar 7 dapat diketahui, bahwa selama bulan November 2011 di pangkal JTR penyulang SRL01 tegangan maksimumnya (Vmaks.) sebesar 220 volt, tegangan minimum (Vmin.) sebesar 199 volt, jumlah pemadaman $1 \mathrm{kali}$, dan lama pemadaman 0,8 jam. Dibandingkan terhadap nilai standar variasi Vmaks. sebesar 230 volt dan Vmin. 197 volt, maka profil variasi tegangan yang terjadi sesuai standar.

Dari Gambar 8 diketahui, bahwa selama bulan November 2011 di tengah JTR penyulang SRL01 Vmaks. sebesar 221 volt, Vmin. sebesar 206 volt, jumlah pemadaman $1 \mathrm{kali}$, dan lama pemadaman 0,8 jam. Dibandingkan terhadap nilai standar variasi Vmaks. sebesar 230 volt dan Vmin. 197 volt, maka profil variasi tegangan yang terjadi sesuai standar. 


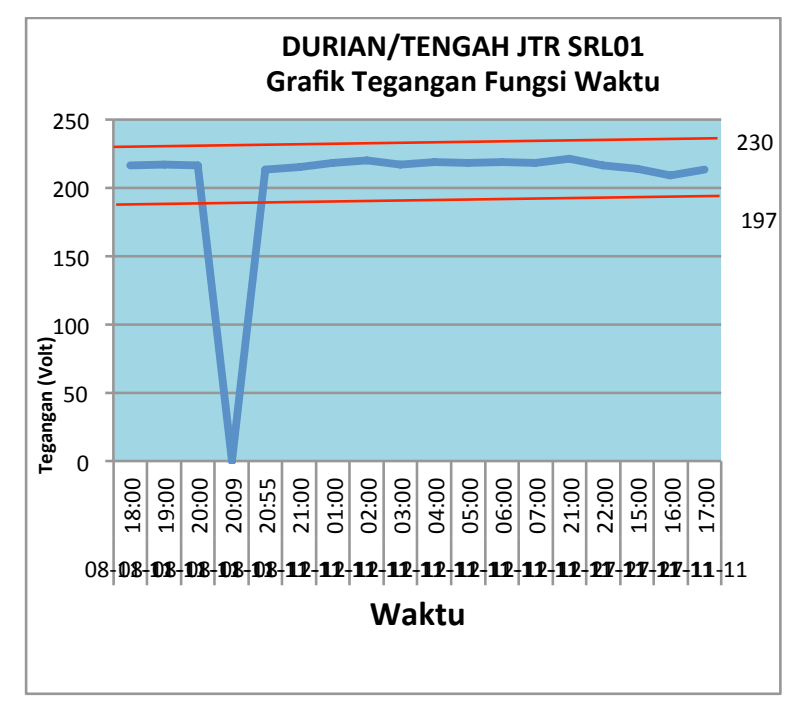

Gambar 8. Profil variasi tegangan di tengah JTR penyulang SRL01

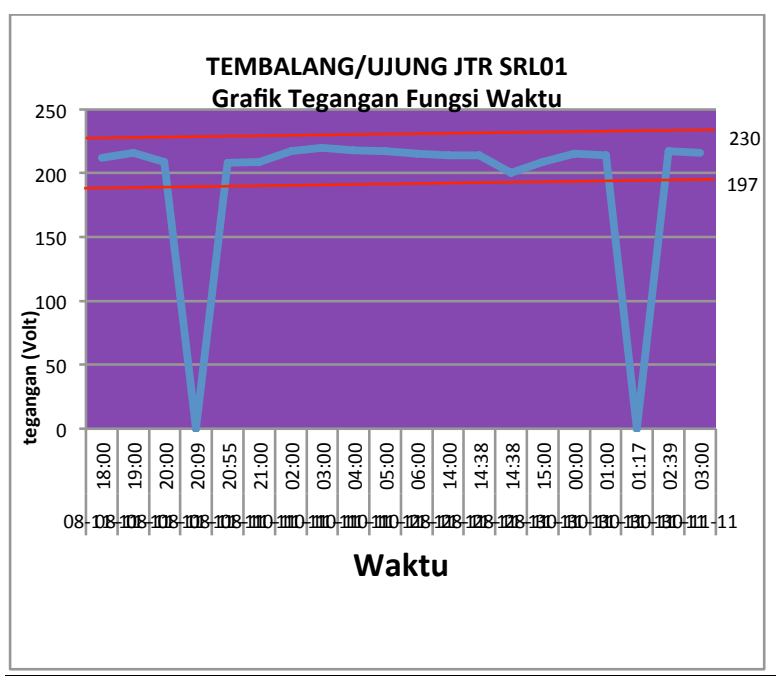

Gambar 9. Profil variasi tegangan di ujung JTR penyulang SRL01

Dari Gambar 9 diketahui pula, bahwa selama bulan November 2011 di ujung JTR penyulang SRL01 Vmaks. sebesar 221 volt, Vmin. sebesar 200 volt, jumlah pmadaman 2 kali, dan lama pemadaman 2,2 jam. Dibandingkan terhadap nilai standar variasi Vmaks. sebesar 230 volt dan Vmin. 197 volt, maka profil variasi tegangan yang terjadi sesuai standar.

\subsection{Variasi Tegangan JTR Penyulang SRL01}

Berdasarkan hasil rekam data selama pengukuran ataupun dari profil variasi tegangan (gambar 3.1, 3.2, dan 3.3), dapat dibuat tabel tegangan maksimal minimal seperti di Tabel 3.
Tabel 3. Nilai Tegangan Maksimal dan Minimal JTR Penyulang SRL01

\begin{tabular}{lllll}
\hline $\begin{array}{c}\text { Tegangan } \\
\text { (Volt) }\end{array}$ & $\begin{array}{c}\text { Pangkal } \\
\text { (Nges } \\
\text { rep) }\end{array}$ & $\begin{array}{c}\text { Tengah } \\
\text { (Du } \\
\text { rian) }\end{array}$ & $\begin{array}{c}\text { Ujung } \\
\text { (Tem } \\
\text { balang) }\end{array}$ & $\begin{array}{c}\text { Stan } \\
\text { dar } \\
\text { PLN }\end{array}$ \\
\hline Maksimum & 220 & 221 & 221 & 230 \\
\hline Minimum & 199 & 206 & 200 & 197 \\
\hline
\end{tabular}

Dari Tabel 3 di atas dapat dibuat grafik tegangan maksimal minimal seperti pada Gambar 10 berikut ini.

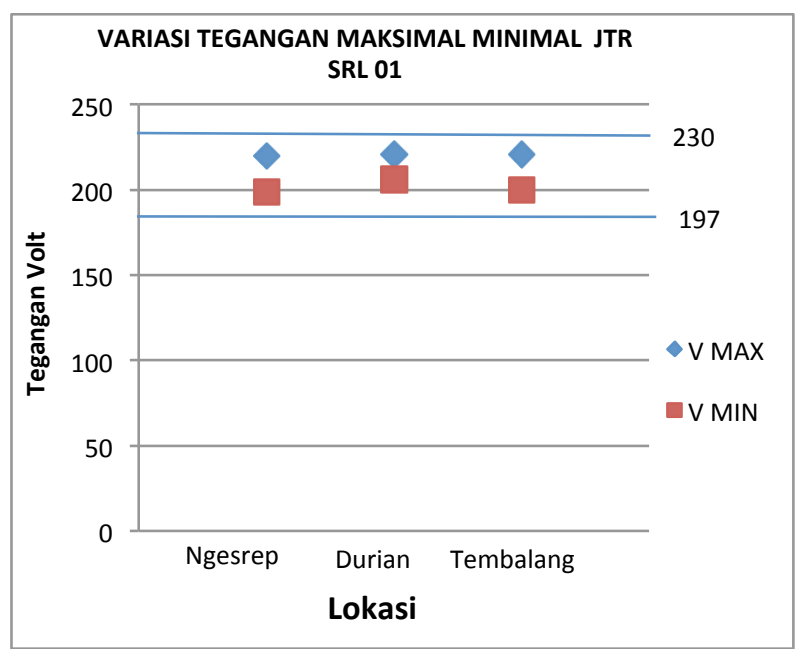

Gambar 10. Grafik variasi tegangan maksimumminimum JTR penyulang SRL01

Tabel 3 dan Gambar 10 menunjukkan bahwa selama periode pengukuran tegangan maksimum dan minimum yang terjadi pada JTR penyulang SRL01 masih di dalam batas standar atau memenuhi standar.

\subsection{Keandalan pada JTR Penyulang SRL01}

Sesuai data, pada JTR penyulang SRL01 mempunyai 17980 pelanggan, dengan rincian: kelompok pelanggan di pangkal JTR $=7458$ pelanggan, kelompok pelanggan di tengah $\mathrm{JTR}=9567$ pelanggan, kelompok pelanggan di ujung JTR=955 pelanggan; dan dari hasil rekam data selama pengukuran), dapat dibuat pula tabel kejadian pemadaman seperti disajikan di Tabel 4.

Jadi dapat dihitung angka SAIDI dan SAIFI sebagai berikut:

$$
\begin{aligned}
& \text { SAIDI } \\
& =\frac{\sum \text { Pelanggan Padam JTR Penyulang SRL } 01 \times \text { Lama Padam }}{\sum \text { Pelanggan }} \\
& =\frac{(7458 \times 0,78)+(9567 \times 0,78)+\{955 \times(0,78+1,33)\}}{17980} \\
& =\frac{(5817,24)+(7462,26)+(2015,05)}{17980}=\frac{15294,55}{17980}
\end{aligned}
$$


Tabel 4. Pemadaman di JTR penyulang SRL01 selama November 2011

\begin{tabular}{|c|c|c|c|c|c|}
\hline \multicolumn{4}{|c|}{ Ngesrep/pangkal JTR SRL01 } & \multicolumn{2}{|c|}{ Standar } \\
\hline $\begin{array}{l}\text { Padam } \\
\text { Ke }\end{array}$ & $\begin{array}{l}\text { Tanggal } \\
\text { Padam }\end{array}$ & $\begin{array}{l}\text { Jam } \\
\text { Mulai }\end{array}$ & $\begin{array}{l}\text { Lama } \\
\text { Padam }\end{array}$ & SAIDI & SAIFI \\
\hline 1 & 08-11-11 & $20: 09$ & 0,78 jam & \multirow{10}{*}{$\begin{array}{l}0,5 \\
\text { Jam/ } \\
\text { Pela } \\
\text { nggan } \\
\text { /bulan }\end{array}$} & \multirow{10}{*}{$\begin{array}{l}2,26 \\
\text { Kali/ } \\
\text { Pela } \\
\text { nggan/ } \\
\text { bulan }\end{array}$} \\
\hline \multicolumn{4}{|c|}{ Durian/tengah JTR SRL01 } & & \\
\hline Padam & Tanggal & Jam & Lama & & \\
\hline $\mathrm{Ke}$ & Padam & Mulai & Padam & & \\
\hline 1 & $08-11-11$ & $20: 09$ & 0,78 jam & & \\
\hline \multicolumn{4}{|c|}{ Tembalang/ujung JTR SRL01 } & & \\
\hline Padam & Tanggal & Jam & Lama & & \\
\hline & Padam & Mulai & Padam & & \\
\hline 1 & $08-11-11$ & $20: 09$ & 0,78 jam & & \\
\hline 2 & $30-11-11$ & $01: 17$ & 1,33 jam & & \\
\hline
\end{tabular}

SAIDI $=0,85 \mathrm{jam} /$ pelanggan $/$ bulan

(standar $S A I D I=0,5 \mathrm{jam} /$ pelanggan/bulan)

$$
\begin{aligned}
& \text { SAIFI } \\
& =\frac{\sum \text { Pelanggan Padam JTR Penyulang SRL01 } \times \text { Kali Padam }}{\sum \text { Pelanggan }} \\
& =\frac{(7458 \times 1)+(9567 \times 1)+(955 \times 2)}{17980} \\
& =\frac{(7458)+(9567)+(1910)}{17980}=\frac{18935}{17980}
\end{aligned}
$$

SAIFI $=1,05 \mathrm{kali} \mathrm{padam} /$ pelanggan $/$ bulan (standar $S A I F I=2,26 \mathrm{kali} /$ pelanggan/bulan).

Dari hasil perhitungan diatas menunjukkan bahwa pada sisi JTR penyulang SRL01:

1. terjadi pemadaman lebih lama dari standar atau melampaui standar.

2. terjadi pemadaman lebih jarang dari standar atau tidak melampaui standar.

\section{Kesimpulan}

adalah:

Kesimpulan yang diperoleh dari penelitian ini

1. Berbasis data logger, maka analisis profil variasi tegangan pada sisi JTR penyulang SRL01 dapat langsung diketahui, yaitu dalam bentuk gambar gelombang variasi tegangan seperti terlihat pada gambar 3.1, 3.2, dan 3.3.

2. Pada sisi JTR penyulang SRL01, variasi tegangan yang terjadi adalah: di pangkal JTR Vmaks $=220$ volt, Vmin $=199$ volt, di tengah JTR Vmaks $=221$ volt, Vmin $=206$ volt, dan di ujung JTR Vmaks = 221 volt, Vmin $=200$ volt; dibandingkan terhadap nilai standar variasi Vmaks $=230$ volt dan Vmin $=$ 197 volt, maka variasi tegangan yang terjadi sesuai standar.
3. Berbasis data logger, maka analisis SAIDI dan SAIFI dapat langsung dilakukan, yaitu dari gambar profil variasi tegangan (gambar 3.1, 3.2, 3.3) dan dari tabel 3.2, terlihat waktu, lama, dan berapa kali terjadi pemadaman selama kurun waktu pengukuran, kemudian dengan menggunakan rumus $S A I D I$ dan $S A I F I$ dapat dihitung.

4. Dari perhitungan, angka lama padam $(S A I D I) \mathrm{di}$ sisi JTR penyulang SRL01 sebesar 0,85 jam/ pelanggan /bulan (belum memenuhi standar) dan angka kali padam (SAIFI) 1,05 kali/ pelanggan/ bulan (sudah memenuhi standar). Hal ini berarti pada JTR penyulang SRL01 keandalannya masih agak kurang, sehingga dapat mengakibatkan kerugian bagi pelanggan karena terganggu aktivitasnya, baik yang bersifat komersil maupun yang lain.

\section{Ucapan Terima Kasih}

Kepada semua pihak yang telah mendukung dan membantu publikasi hasil penelitian ini, penulis mengucapkan banyak terima kasih.

\section{Daftar Pustaka}

Standar PLN (SPLN) No. 59. 1985. "Keandalan Pada Sistem Distribusi $20 \mathrm{kV}$ dan 6kV". Jakarta: Departemen Pertambangan dan Energi.

T.A., Short. 2004, "Electrical Power Distribution Handbook", CRC Press, London-NewYork Washington DC.

PLN PT. 2010, "Revisi RUPTL (Rencana Umum Penyediaan Tenaga Listrik) 2010-2019, PT PLN Persero, Jakarta.

Anto, HP. 2008. "Kendala Perhitungan SAIDI SAIFI". www.plnbabel.co.id

SE. Direksi. 2002, "Tingkat Mutu dan Pelayanan /TMP PLN", PT PLN Persero, Jakarta.

Saodah, Siti. 2008, "Evaluasi Keandalan Sistem Distribusi Tenaga Listrik Berdasarkan SAIDI\& SAIFI", Teknik Elektro Institut Teknologi Nasional, Jogjakarta.

Richard E. Brown. 2009. "Electrical Power Distribution Reliability", Second Edition, CRC Press, London, NewYork.

P3B Jawa-Bali. 2011, “Operasi Sistem Jawa Bali”, PT PLN Persero, Jakarta.

Jasa Pendidikan dan Pelatihan. 2008. "Pengoperasian Sistem Distribusi", PT PLN Persero, Jakarta.

Sudjadi. 2009, “TMP Recorder”, www.electro. undip.ac.id 